Acta vet. scand. $1978,19,84-92$.

From the Department of Animal Hygiene, College of Veterinary Medicine, Helsinki, Finland.

\title{
HEMATOLOGICAL AND BLOOD CHEMICAL DATA OF PIGS FED VARIOUS AMOUNTS OF MINK MANURE
}

\author{
By \\ Matti Näsi ${ }^{\star}$, Hannu Saloniemi and Kaarlo Kallela
}

\begin{abstract}
NÄSI, M., H. SALONIEMI and K. KALLELA: Hematological and blood chemical data of pigs fed various amounts of mink manure. Acta vet. scand. 1978, 19, 84-92. - The effect of feeding mink manure to pigs and the utilization of its protein and mineral content was studied by blood analyses. Individual variation was large, and the differences between groups were small. Growth of the animals had a significant effect on the levels of several blood components. Judging from the blood analyses, mink manure feeding did not have any harmful effects on the health of the pigs, and the differences to normal feeding were small.
\end{abstract}

mink manure; pig; blood; waste utilization.

The question of environmental pollution and efforts towards appropriate and unwasteful use of raw materials have made great interest in the recycling of waste and by-products. Many wastes have a high nutritional value and they have been successfully fed to domestic animals as substitutes for valuable conventional feeds (Blair \& Knight 1973a, b).

Because of difficulties with manure disposal in large production units, the manure has been dehydrated and used as feedstuff (Blair 1974).

In Finland, like in many other countries, the use of manure as feed is prohibited by law. The reason for this is the possibility of harmful effects on the consuming animal by chemicals and medical compounds or their metabolites possibly remaining in the manure. The manure may also contain pathogenic micro-

* Present address: the Department of Animal Husbandry, University of Helsinki, Finland. 
organisms or parasite ova, which via the manure may spread from one animal to another or into animal products. When the manure is dehydrated by heat the microbes are destroyed. In spite of heat processing certain toxins may remain in the manure (Taylor et al. 1974, Bhattacharya \& Taylor 1975, Platz 1975).

The purpose of the present investigation was to study, by blood analyses, possible harmful effects of mink manure feeding on pigs and the value of its protein and mineral components.

\section{MATERIAL AND METHODS}

A total number of 180 blood samples were collected from 36 pigs of Yorkshire and Landrace breeds subjected to 2 separate feeding experiments with mink manure. In each experiment the pigs were divided into 3 equal groups of 6 animals each. The control groups were fed a normal commercial complete feed, and to the other groups 7.5 or $15 \%$ of the complete feed was substituted with dehydrated mink manure and ground barley (Table 1). The mineral supply of the pigs is presented in Table 2. The weight and weight gain of the pigs at each sampling are given in Table 3 .

In both experiments sampling was done at the start of the experiment and after 28 and 56 days, respectively, on 2 successive days. In the second experiment duplicate samples were taken in the beginning of the experiment only. Sampling was done before the morning feeding, i.e. 16 hrs. after the preceding feeding. Water was kept available ad lib.

The blood samples were taken by syringe from the anterior vena cava while the pigs were kept on a rack in dorsal recum-

T a b le 1. Average daily feed intake in different sampling periods.

\begin{tabular}{|c|c|c|c|c|c|c|c|c|c|c|c|}
\hline \multirow[b]{2}{*}{$\begin{array}{l}\text { Experi- } \\
\text { ment }\end{array}$} & \multirow[b]{2}{*}{ Days } & \multicolumn{2}{|c|}{ Group I } & \multicolumn{4}{|c|}{ Group II } & \multicolumn{4}{|c|}{ Group III } \\
\hline & & $\begin{array}{l}\text { complete } \\
\text { feed, } \mathrm{kg}\end{array}$ & f.u. & $\begin{array}{l}\text { complete } \\
\text { feed, kg }\end{array}$ & $\begin{array}{c}\text { barley, } \\
\text { kg }\end{array}$ & $\begin{array}{c}\text { mink } \\
\text { manure, } \\
\text { kg }\end{array}$ & f.u. & $\begin{array}{l}\text { complete } \\
\text { feed, } \mathrm{kg}\end{array}$ & $\begin{array}{l}\text { barley, } \\
\text { kg }\end{array}$ & $\underset{\text { manure, }}{\operatorname{mink}}$ & f.u. \\
\hline 1 & 0 & 1.20 & 1.19 & 1.02 & 0.09 & 0.09 & 1.14 & 0.87 & 0.17 & 0.17 & 1.10 \\
\hline 1 & 28 & 1.82 & 1.82 & 1.54 & 0.14 & 0.14 & 1.74 & 1.26 & 0.28 & 0.28 & 1.66 \\
\hline 1 & 56 & 2.45 & 2.44 & 2.08 & 0.18 & 0.18 & 2.33 & 1.72 & 0.37 & 0.37 & 2.24 \\
\hline 2 & 0 & 1.20 & 1.18 & 1.03 & 0.08 & 0.08 & 1.13 & 0.87 & 0.17 & 0.17 & 1.10 \\
\hline 2 & 28 & 1.85 & 1.81 & 1.57 & 0.14 & 0.14 & 1.73 & 1.28 & 0.28 & 0.28 & 1.66 \\
\hline 2 & 56 & 2.60 & 2.54 & 2.00 & 0.20 & 0.20 & 2.26 & 1.80 & 0.40 & 0.40 & 2.33 \\
\hline
\end{tabular}


T a b l e 2. Average amounts of minerals and trace elements obtained from experimental feeds daily per pig.

\begin{tabular}{|c|c|c|c|c|c|}
\hline \multicolumn{2}{|c|}{ Element } & $\frac{\text { Group period }}{1}$ & Group I & $\begin{array}{c}\text { Group II } \\
8.7\end{array}$ & $\begin{array}{c}\text { Group III } \\
9.9\end{array}$ \\
\hline $\mathbf{P}$ & g & $\begin{array}{l}1 \\
\mathbf{2} \\
\mathbf{3}\end{array}$ & $\begin{array}{r}7.3 \\
10.2 \\
14.8\end{array}$ & $\begin{array}{r}8.7 \\
13.1 \\
19.4\end{array}$ & $\begin{array}{r}9.9 \\
15.9 \\
23.9\end{array}$ \\
\hline $\mathrm{Ca}$ & g & $\begin{array}{l}1 \\
2 \\
3\end{array}$ & $\begin{array}{l}2.9 \\
4.1 \\
6.3\end{array}$ & $\begin{array}{l}3.7 \\
5.5 \\
8.5\end{array}$ & $\begin{array}{r}4.3 \\
6.9 \\
10.7\end{array}$ \\
\hline Mg & g & $\begin{array}{l}1 \\
2 \\
3\end{array}$ & $\begin{array}{l}2.0 \\
2.9 \\
4.0\end{array}$ & $\begin{array}{l}2.3 \\
3.2 \\
4.5\end{array}$ & $\begin{array}{l}2.5 \\
3.7 \\
5.1\end{array}$ \\
\hline $\mathbf{N a}$ & g & $\begin{array}{l}1 \\
2 \\
3\end{array}$ & $\begin{array}{l}3.0 \\
4.2 \\
4.8\end{array}$ & $\begin{array}{l}3.1 \\
4.3 \\
5.2\end{array}$ & $\begin{array}{l}3.1 \\
4.3 \\
5.6\end{array}$ \\
\hline $\mathbf{K}$ & g & $\begin{array}{l}1 \\
2 \\
3\end{array}$ & $\begin{array}{r}6.2 \\
8.6 \\
11.8\end{array}$ & $\begin{array}{r}6.4 \\
8.9 \\
12.3\end{array}$ & $\begin{array}{r}6.5 \\
9.3 \\
12.9\end{array}$ \\
\hline $\mathrm{Fe}$ & $\mathrm{mg}$ & $\begin{array}{l}1 \\
2 \\
3\end{array}$ & $\begin{array}{l}215 \\
297 \\
416\end{array}$ & $\begin{array}{l}254 \\
379 \\
522\end{array}$ & $\begin{array}{l}285 \\
460 \\
630\end{array}$ \\
\hline $\mathrm{Cu}$ & $\mathrm{mg}$ & $\begin{array}{l}1 \\
2 \\
3\end{array}$ & $\begin{array}{r}84 \\
120 \\
153\end{array}$ & $\begin{array}{r}76 \\
96 \\
124\end{array}$ & $\begin{array}{r}75 \\
98 \\
124\end{array}$ \\
\hline $\mathrm{Zn}$ & $\mathrm{mg}$ & $\begin{array}{l}1 \\
2 \\
3\end{array}$ & $\begin{array}{l}112 \\
151 \\
210\end{array}$ & $\begin{array}{l}146 \\
211 \\
300\end{array}$ & $\begin{array}{l}175 \\
255 \\
391\end{array}$ \\
\hline Mn & $\mathrm{mg}$ & $\begin{array}{l}1 \\
2 \\
3\end{array}$ & $\begin{array}{r}72 \\
107 \\
137\end{array}$ & $\begin{array}{r}84 \\
118 \\
156\end{array}$ & $\begin{array}{r}93 \\
128 \\
176\end{array}$ \\
\hline
\end{tabular}

T a b l e 3. Average weights and daily gains of the pigs at different sampling times.

\begin{tabular}{|c|c|c|c|c|c|c|c|}
\hline \multirow[b]{2}{*}{$\begin{array}{l}\text { Experi- } \\
\text { ment }\end{array}$} & \multirow[b]{2}{*}{ Group } & \multicolumn{3}{|c|}{ Live weight, $\mathrm{kg}$} & \multicolumn{3}{|c|}{ Daily gain, g/day } \\
\hline & & 0 day & 28 days & 56 days & 0 day & 28 days & 56 days \\
\hline \multirow{3}{*}{1} & I & 21.0 & 36.7 & 51.6 & 440 & 662 & 821 \\
\hline & II & 20.8 & 34.8 & 50.8 & 333 & 590 & 833 \\
\hline & III & 20.3 & 33.8 & 47.6 & 269 & 633 & 755 \\
\hline \multirow{3}{*}{2} & I & 20.3 & 40.1 & 64.3 & 707 & 714 & 881 \\
\hline & II & 20.4 & 39.0 & 61.2 & 667 & 774 & 786 \\
\hline & III & 20.4 & 37.7 & 58.2 & 700 & 655 & 750 \\
\hline
\end{tabular}


bency. The samples for chemical analysis were transferred to heparinized test tubes and those intended for hematological determinations to EDTA (tetracemindikol. $5.5 \mathrm{mg}$ ) tubes. The heparinized tubes were immediately centrifuged and the plasma decanted. Determinations of glucose, urea and protein in plasma were carried out immediately. Plasma was stored deep frozen, and determinations of minerals and trace elements were made from all samples at the same time. From the EDTA tubes hemoglobin and hematocrit were determined. The following methods were used:

Hemoglobin, the cyanmethemoglobin method in a Beckman B spectrophotometer at wave-length $540 \mathrm{~nm}$.

Hematocrit, centrifuging for 5 min. at 1500 r.p.m. in a Microhaematocrite Centrifuge Heraeus-Christ type 912.

Glucose, the O-Toluidine-method (Hyvärinen et al. 1972, p. 206).

Protein, the Biuret-method (Hyvärinen et al., p. 359).

Urea, the Bertholt phenol-hypoclorite-method (Hyvärinen et al., p. 412).

Inorganic phosphate, the Molybdate-blue-method (Henry et al. 1974). Calcium, magnesium, potassium and sodium, in a Perkin Elmer atomic absorption spectrophotometer.

Iron, zinc and copper, in a Varian Techtron AA 1000 atomic absorption spectrophotometer.

\section{RESULTS AND DISCUSSION}

The hematological and blood chemical results are presented in Tables 4 and 5 . With the exception of a few values, the obtained results correspond with those presented in previous literature. Investigations on blood composition of pigs are scanty and great variations occur between the recorded normal values, due to differences in methods used and the varying general conditions of the pigs.

Variation within the groups was rather wide, which caused little variation between the groups. Between samplings, differences due to increasing age and weight of the animals occurred.

Blood hemoglobin and hematocrit rose in all groups during experiments $\left(r=0.465^{\star \star \star}\right.$ and $\left.r=0.603^{\star \star \star}\right)$. In the controls the $\mathrm{Hb}$ and $\mathrm{Hc}$ values were on an average higher than in the pigs fed manure, and as far as $\mathrm{Hc}$ is concerned the difference was significant $(P<0.01)$. In Experiment 2 the values were significantly higher than in Experiment $1(\mathrm{P}<0.01)$, which was obviously associated with better growth. 


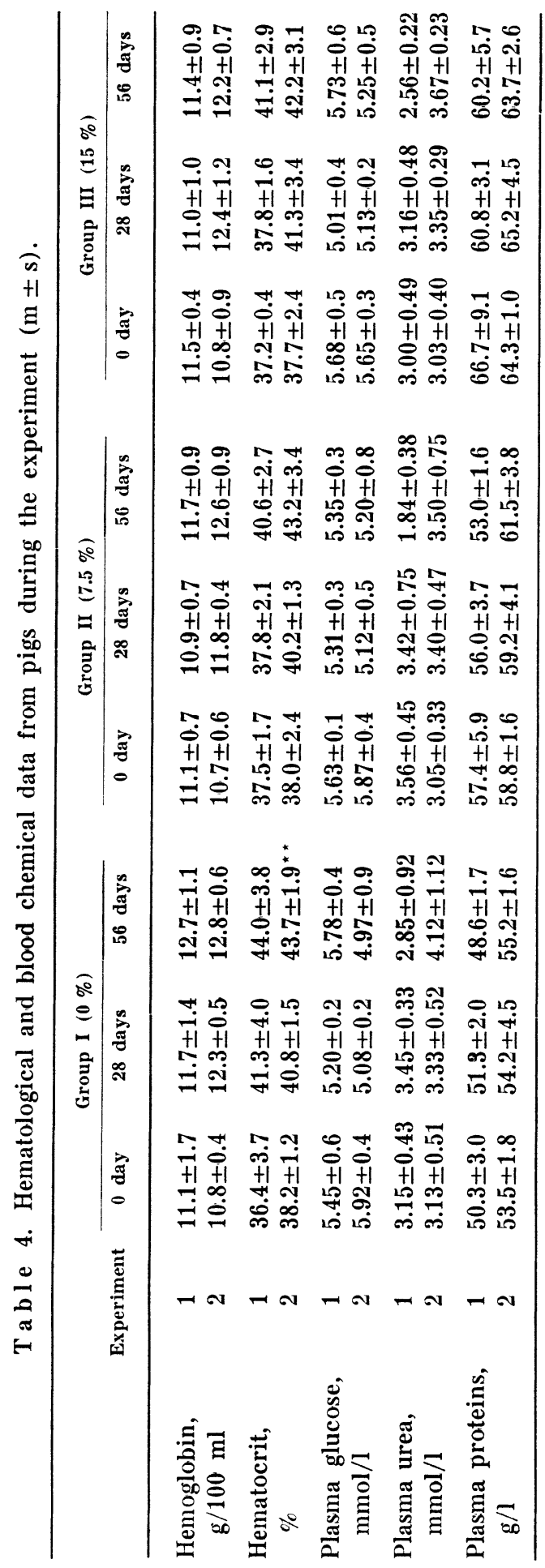




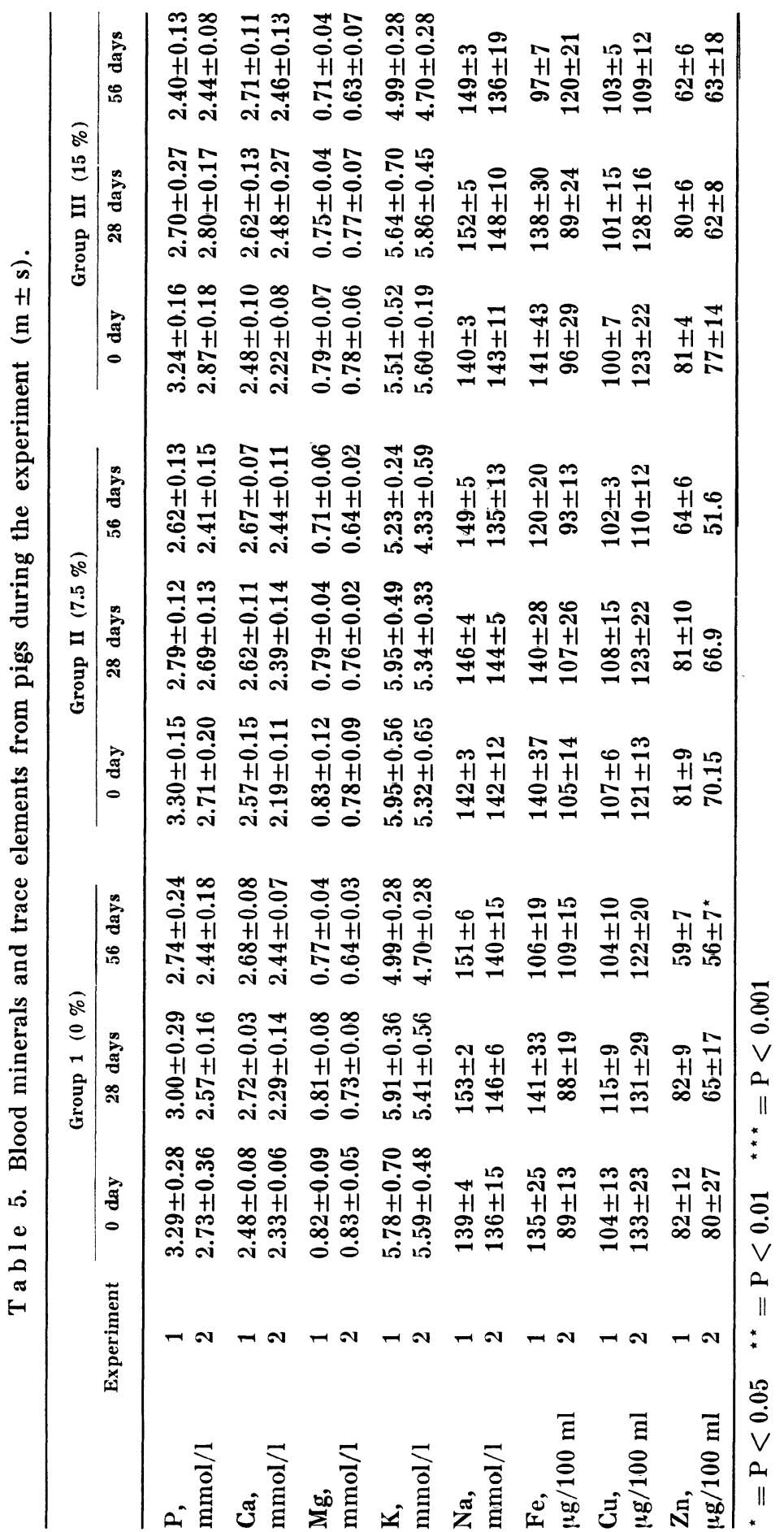


Plasma glucose decreased in the course of the growth of the animals $\left(r=-0.257^{\star \star \star}\right)$. The pigs' energy supply was restricted according to the high-low standards applied. No detectable differences occurred between groups.

Plasma urea was on an average $0.20 \mathrm{mmol} / \mathrm{l}$ higher in the controls than in the experimental groups. Experiments 1 and 2 differed very markedly $(P<0.01)$ in this respect. In Experiment 1 the values sank and in Experiment 2 they rose as the animals grew. The plasma urea level is reciprocally proportional to weight gain and feed utilization (Puchal et al. 1962). In Experiment 2 weight gain and feed utilization were better than in Experiment 1. Plasma urea was dependent on the amount and quality of feed protein. When the biological value of dietary protein rises, plasma urea sinks (Münchow \& Bergner 1968, Eggum 1970). These experiments could not show that the protein value of mink manure would differ from that of conventional protein sources. The obtained plasma protein values were somewhat lower than those listed in the literature (Haaranen 1960, Cornelius \& Kaneko 1963, Seidel 1972, Wilson et al. 1972), but they correspond to those given by Miller \& Payne (1961). As the pigs grew, the plasma protein values rose very significantly ( $r$ $\left.=0.708^{\star \star}\right)$. The protein level was highest in the controls and sank on an average $0.7 \mathrm{~g} / \mathrm{l}$ by each $7.5 \%$ addition of mink manure. Changes in serum protein levels can be accomplished only when the dietary protein levels are very low (Wilson et al.).

Inorganic phosphorus sank during the experiment $(\mathbf{r}=$ $\left.-0.634^{\star \star \star}\right)$. The two experiments differed as to their results, and in Experiment 2 the decrease of $P$ was smaller. The values obtained correspond to those reported by Seidel. Plasma calcium rose with the age of the pigs $\left(r=0.398^{\star \star \star}\right)$. Variation between groups was small and the values are in accordance with those given by Cornelius \& Kaneko, but are lower than those reported by Seidel. The magnesium levels of the pigs were generally low as compared to those listed in the literature. The mean was $0.75 \pm 0.09 \mathrm{mmol} / \mathrm{l}$. Magnesium sank steeply in the beginning of the experiments $\left(\mathrm{r}=-0.576^{\star \star \star}\right)$. At the third sampling in Experiment 2, the mean values were very low, $0.63-0.63 \mathrm{mmol} / \mathrm{l}$. Plasma potassium sank $\left(r=-0.500^{\star \star \star}\right)$. No difference in sodium levels were observed. The iron level was a little higher in groups receiving mink manure than in the controls. The values varied between 45 and $195 \mu \mathrm{g} / 100 \mathrm{ml}$. The copper level was 
higher in the controls ( $\mathrm{P}<\mathbf{0 . 0 5}$ ). The control groups also received on an average more copper. The values obtained were only about half as high as those reported by Dunne (1964) and Seidel. Plasma zinc levels sank steeply as the animals grew ( $\left.\mathrm{r}=-0.534^{\star \star \star}\right)$. Zinc levels lower than those obtained in this experiment have been reported (Seidel).

Feed consumption of individual pigs was not closely recorded and because of this exact correlations between feed composition and chemical composition of blood can not be drawn. The mineral content of the mink manure was high. Its utilization, however, was obviously not so good. Feeding mink manure did not have any negative effects on the health of the pigs, nor did it cause any great changes in blood composition as compared to normal feeding.

\section{REFERENCES}

Bhattacharya, A. N. \& J. C. Taylor: Recycling animal waste as a feedstuff: a review. J. Anim. Sci. 1975, 41, 1438-1457.

Blair, R.: Utilization of wastes and by-products in animal feeds. Feedstuffs $1974,46,39,19-24$.

Blair, R. \& D. W. Knight: Recycling animal wastes. I. Feedstuffs 1973a, $45,10,32-34$.

Blair, R. \& D. W. Knight: Recycling animal wastes. II. Feedstuffs $1973 \mathrm{~b}, 45,12,31-35$.

Cornelius, C. E. \& J. J. Kaneko, (eds.) : Clinical Biochemistry of Domestic Animals. New York and London 1963, $678 \mathrm{pp}$.

Dunne, H. W.: Diseases of Swine. 2nd Ed. Ames, Iowa 1964, 897 pp.

Eggum, B. O.: Blood urea measurement as a technique for assessing protein quality. Brit. J. Nutr. 1970, 24, 983-988.

Haaranen, S.: Some blood components of growing pigs. Nord. Vet.Med. 1960, 12, $239-244$.

Henry, R. J., D. C. Cannon \& J. W. Winkelman: Clinal Chemistry: Principles and Technics. 2nd Ed. New York 1974, 1629 pp.

Hyvärinen, A., J. Jännes, E. Nikkilä, N.-E. Saris \& P. Voipio: Kliiniset laboratoriotutkimukset. (Clinical laboratory investigations). Porvoo 1972, $581 \mathrm{pp}$.

Miller, D. S. \& P. R. Payne: Problems in the production of protein values of diets. The influence of protein concentration. Brit. J. Nutr. 1961, 15, 11-19.

Münchow, H. \& H. Bergner: Empfehlung zur Proteinbewertung von Eiweissfuttermitteln anhand der Bestimmung der Harnstoffkonzentration im Blut von Ratte oder Schwein. (Recommendations for the protein estimation of protein feed by analysis of the concentration of urea in the blood of rats and pigs). Arch. Tierernähr. 1968, 18, 222-228. 
Platz, S.: Hygienisierung und Verwertungsmöglichkeit von Geflügelkot und -einstreu - eine Litteraturübersicht. (Hygienic questions connected with recycling of poultry manure and litter). Arch. Geflügelkde 1975, 5, 158-166.

Puchal, R., V. W. Hays, V. C. Speer, J. D. Jones \& D. W. Catron: The free blood plasma amino acids of swine as related to the source of dietary proteins. J. Nutr. 1962, 76, 11-16.

Seidel, H.: Physiologische Mittel- und Grenzwerte. Sweinekrankenheiten. (Physiological mean and limit values. Diseases in pigs). Ed. R. Neudorf \& H. Seidel. Jena 1972, 29-56.

Taylor, J. C., D. A. Gable, G. Graber \& E. W. Lucas: Health criteria for processed wastes. Fed. Proc. 1974, 33, 1945-1946.

Wilson, G. D. A., D. G. Harvey \& C. R. Snook: A review of factors affecting blood biochemistry in the pig. Brit. vet. J. 1972, 128, $596-610$.

\section{SAMMANFATTNING}

Hematologiska och kemiska blodvärden hos gödsvin matade med varierande mängd minkgödsel.

Effekten av minkgödseltillskott $i$ fodret åt gödsvin och tillgodogörelsen av dess protein- och mineralinnehåll studerades genom blodundersökningar. Den individuella variationen var stor och skillnaderna mellan försöksgrupperna små. Ett flertal blodvärden påverkades i signifikant grad av djurens tillväxt. Av blodundersökningarna att döma hade tillskotten av minkgödsel ingen som helst negativ inverkan på svinens hälsotillstånd, och skillnaderna till normal utfodring var obetydliga.

(Received September 5, 1977).

Reprints may be requested from: Matti Näsi, the Department of Animal Husbandry, University of Helsinki, 00710 Helsinki 71, Finland. 